\title{
PENGARUH STRES KERJA, KEPUASAN KERJA, DAN KEPUASAN ATAS GAJI TERHADAP TURNOVER INTENTION KARYAWAN (PT. Adira Semesta Idustry Cabang II Sumedang)
}

\author{
Agus Alamsyah $\mathbf{P},{ }^{1}$, Intan Kusumadewi, ${ }^{2}$ \\ ${ }^{1}$ ) Manajemen, FISIP UIN Sunan Gunung Djati Bandung \\ email: agus_ve_smd@yahoo.co.id \\ $\left.{ }^{2}\right)$ Teknik Industri, Fakultas Teknik Universitas Majalengka \\ email: intan_kdewi@yahoo.com
}

\begin{abstract}
ABSTRAK
Pada penelitian ini responden yang digunakan adalah karyawan di bidang produksi yang terbagi menjadi beberapa bagian dan staf dan direksi PT.Adira Semesta Industry yang disesuaikan dengan teknik stratified random sampling yang melibatkan strata(tingkatan) dalam pemilihan responden secara random yang berjumlah 75 orang karyawan di PT Adira Semesta Industry. Uji yang digunakan untuk menguji hipotesis menggunakan Uji t, dan Uji F, sedangkan untuk menganalisis data, yang digunakan adalah analisis regresi berganda koefisien determinasi, adapun perhitungan dalam mengolah data ini dibantu program Spss Versi 20.

Hasil penelitian ini menunjukkan pengaruh stres kerja, kepuasan kerja, dan kepuasan atas gaji terhadap Turnover intentionsebesar 30,5\% sedangkan sisanya $69,5 \%$ dipengaruhi oleh factor-faktor lainnya yang tidak diteliti dalam penelitian ini. Selanjutnya berdasarkan pengujian hipotesis secara parsial (Uji t) dan simultan (Uji F), maka didapatkan hasil yaitu secara simultan variabel stres kerja, kepuasan kerja, kepuasan atas gaji berpengaruh positif dan signifikan terhadap Turnover intention denganF ${ }_{\text {hitung }}>$ $\mathrm{F}_{\text {tabel }} 10,375>3,12$. Secara parsial sres kerja berpengaruh positif dan signifikan dengan hasil $t_{\text {hitung }}>t_{\text {tabel }}$, yaitu 4,240 > 1,6666 dengan tingkat signifikansi 0,000, kepuasan kerja berpengaruh negatif dengan hasil $t_{\text {hitung }}>t_{\text {tabel }}$, yaitu $-2,436>1,6666$, dan kepuasan atas gaji berpengaruh negatif dan signifikan dengan hasil $t_{\text {hitung }}>t_{\text {tabel }}$ yaitu $-3,465>1,6666$ dengan tingkat signifikansi 0,001 .
\end{abstract}

\section{Keywords: Stres Kerja, Kepuasan Kerja, Dan Kepuasan Atas Gaji Terhadap Turnover Intention}

\section{PENDAHULUAN}

Perkembangan terbaru memandang SDM bukan sebagai sumber daya belakang, melainkan lebih berupa modal atau aset bagi institusi atau organisasi. Karena itu munculah istilah baru diluar HR (Human Resources), yaitu HC atau Human Capital. Disini SDM dilihat bukan sebagai aset utama, tetapi aset yang bernilai dapat dilipat gandakan, dikembangkan dan juga bukan sebaliknya sebagai liability (beban cost), disini perspektif SDM sebagai investasi bagi institusi atau organisasi lebih mengemuka.

Karena kejadian-kejadian tersebut tidak dapat diperkirakan, kegiatan-kegiatan pengembangan harus mempersiapkan setiap saat pengganti karyawan yang keluar. Di lain pihak, dalam banyak kasus nyata, program pengembangan perusahaan yang sangat baik justru meningkatkan turnover intentions. Pergantian karyawan atau keluar masuknya karyawan dari organisasi adalah suatu fenomena penting dalam kehidupan organisasi. Ada kalanya pergantian karyawan memiliki dampak positif. Namun sebagian besar pergantian karyawan membawa pengaruh yang kurang baik terhadap organisasi, baik dari segi biaya maupun dari segi hilangnya waktu dan kesempatan untuk memanfaatkan peluang Dalam arti luas, turnover diartikan sebagai aliran para karyawan yang masuk dan keluar perusahaan (Ronodipuro dan Husnan, 1995: 34). Banyak faktor yang dapat mempengaruhi adanya Turnover Intention pada perushaan yang faktor yang sering banyak di jumpai adalah stres kerja,kepuasan kerja dan kepuasan gaji karyawan dan faktor-faktor lain. 
Salah satu prediktor lain yang menyebabkan keinginan untuk berhenti bekerja pada perusahaan yaitu kepuasan terhadap gaji. Individu merasakan adanya rasa keadlian (equity) terhadap gaji yang diterima sehubungan dengan pekerjaan yang dilakukannya. Lum et al dan Handoko menyatakan bahwa perusahaan harus memperhatikan prinsip keadilan dalam penetapan kebijaksanaan pembayaran gaji. Kepuasan atas gaji yang diterima didasarkan pada teori equity yang berkenaan dengan motivasi individu untuk bertindak dalam organisasi. Individu akan menilai rasio input terhadap outcome untuk tugas yang ada dan membandingkan dengan karyawan lain(referen). Ketidak puasan terhadap gaji yang diterima seringkali dianggap sebagai alasan penting yang menyebabkan individu meninggalkan pekerjaannya. Dengan kata lain dapat disimpulkan bahwa kepuasan dan ketidakpuasan atas gaji yang diterima ini berpengaruh langsung pada pembentukan niat untuk keluar.

Untuk dapat mengukur respon emosional individu terhadap aspek-aspek dalam pekerjaannya, penelitian ini menggunakan 4 dimensi faktor kepuasan terhadap gaji milik Haneman \& Schwab 1988 dalam Adini Rita (2006). 4 Dimensi tersebut yaitu: tingkat gaji (pay level), struktur/pengelolaan gaji (paystructure and administration), peningkatan gaji (pay raise) dan yang terakhir adalah tunjangan (benefit).

Penelitian ini dilakukan di salah satu perusahaan yang bernama PT Adira Semesta Industry yang terletak di jalan raya parakanmuncang $\mathrm{km} 20$ Kab Sumedang perusahan ini bergerak di bidang industri exspor sarung tangan golf ke beberapa negara yaitu Jepang, Korea, dan Eropa. Untuk menggambarkan tingkat turnover di PT.Adira Semesta Industry cabang II Sumedang, peneliti melakukan wawancara secara langsung terhadap salah satu personalia yang ada di PT.Adira Semesta Industry cabang II Sumedang tentang data turnover. Setelah dilakukan wawanacara langsung peneliti mendapatkan data yang menggambarkan turnover di PT.Adira Semesta Industy tersebut sejak tahun 2012 hingga 2014:
Tabel 1.1

Data Turnover Karyawan

\begin{tabular}{|l|c|c|c|c|}
\hline Tahun & $\begin{array}{c}\text { Jumlah } \\
\text { karyaw } \\
\text { an } \\
\text { awal } \\
\text { tahun }\end{array}$ & $\begin{array}{c}\text { Jumlah } \\
\text { karyaw } \\
\text { an } \\
\text { yang } \\
\text { keluar }\end{array}$ & $\begin{array}{c}\text { Jumlah } \\
\text { karyaw } \\
\text { an } \\
\text { yang } \\
\text { masuk }\end{array}$ & $\begin{array}{c}\text { Jumlah } \\
\text { karyaw } \\
\text { an akhir } \\
\text { tahun }\end{array}$ \\
\hline 2012 & 268 & 4 & 7 & 271 \\
\hline 2013 & 271 & 5 & 6 & 272 \\
\hline 2014 & 272 & 2 & 8 & 278 \\
\hline
\end{tabular}

Sumber PT Adira Semesta Industry

Dilihat dari data tersebut walaupun tingkat keluar karywan sedikit tetapi niat keluar dari karyawan yang bekerja di PT Adira Semesta Industry cabang II Sumedang cukup beragam ada yang di pengaruhi dari stres kerja adapun dari kepuasan kerja dan kepuasan gaji menurut salah satu karyawan yang di wawancara langsung oleh peneliti dengan mengambil salah satu karyawan di bagian produksi menyatakan bahwa Pelaksanaan tugas yang belum bisa mencapai pemenuhan target yang lebih efektif dan efisien, melainkan lebih berorientasi kepada pelaksanaan tuggas yang kurang memperhatikan kondisi karyawan karena disebabkan dealine penyelesaian tugas, tuntutan peran di tempat kerja yang semakin beragam dan kadang terjadi pertentangan satu dengan yang lain,masalah keluarga,beban kerja yang berlebihan,dan diduga juga pegawai kejenuhan dalam pekerjaannya dan salah faktor dari luar pekerjaan yang dapat mempengaruhi stres kerja kebanyakan muncul dari stress off the job. Sedangan kepuasan kerja yang di dapat terasa masih kurang karena kepuasan kerja adalah suatu kondisi dimana karyawan pendapatkan kepuasan dalam bekerja yang akan menghasilkan feedback pada perusahaaan dengan baik karena adanya motivasi,dan kerjasama antar karyawan,imbalan yang diterima dalam kerja. Hal tersbut masih kurang dirasakan oleh sebagaian karyawan yang ada di PT. Adira Semesta Industry cabang II Sumedang sedangan kepuasan gaji yang ada di sesuaikan dengan UMR yang ada di Kab.Sumedang menurut salah satu karywan masih kurang karena kebutuhan nya melebihi dari gaji tersebut. 
Penelitian ini mengambil objek karyawan PT.Adira Semesta Industry di cabang II Sumedang, perusahaan ini memproduksi penyamak kulit sarungan golf untuk exspor. Jika Turnover Intention karywan rendah maka karywan dapat menghasilkan kualitas produk yang baik. Dalam melaksanakan tugasnya bagian produksi sangat lah penting karena Sumber Daya manusia yang ada di bagian produksi adalah salah satu bagian yang lebih banyak berhubungan langsung dengan produk yang akan di buat. Para karyawan di bagian produksi tentunya tidak terlepas dari pengaruh stres kerja, kepuasan kerja, dan kepuasan gaji.

Berdasarkan latar belakang penelitian yang telah di uraikan di atas, maka peneliti memberikan rumusan masalah sebagai berikut :

1. Seberapa besar pengaruh stres kerja terhadap Turnover Intention di PT. Adira Semesta Industry?

2. Seberapa besar pengaruh kepuasan kerja terhadap Turnover Intention di PT. Adira Semesta Industry?

3. Seberapa besar pengaruh kepuasan gaji terhadap Turnover Intention di PT. Adira Semesta Industry?

4. Seberapa besar pengaruh stres kerja,kepuasan kerja dan kepuasan gaji terhadap Turnover Intention di PT. Adira Semesta Industry?

\section{METODE PENELITIAN}

Metode penelitian yang digunakan dalam penelitian ini adalah metode kuantitatif dengan menggunakan instrumen quisioner. Metode Penelitian Kuantitatif, sebagaimana dikemukana oleh Sugiyono (2009:14) dapat diartikan sebagai metode penelitian yang berlandaskan pada filsafat positivisme, digunakan untuk meneliti pada populasi atau sampel tertentu, teknik pengambilan sampel pada umumnya dilakukan secara random, pengumpulan data menggunakan instrumen penelitian, analisis data bersifat kuantitatif/statistik dengan tujuan untuk menguji hipotesis yang telah ditetapkan. Penelitian yang dilakukan penulis dilaksanakan di PT. Adira Semesta Industry

Desain penelitian yang akan digunakan dalam penelitian ini adalah menggunakan survey explanatory research. Instrumen penelitian yang digunakan untuk memperoleh data primer di lapangan adalah kuisioner tertutup.

\section{Populasi Dan Sampel}

\section{A. Populasi}

Populasi adalah wilayah generalisasi yang terdiri atas atas objek/subyek yang mempunyai kualitas dan karakteristik tertentu yang ditetapkan oleh peneliti untuk dipelajari dan kemudian ditarik kesimpulannya (Sugiyono, 2011 :90).

Populasi dalam penelitian ini adalah seluruh karyawan di PT. Adira Semesta Industry yang berjumlah 278 orang karyawan.

\section{B. Sampel}

Sampel adalah bagian dari jumlah dan karakteristik yang dimiliki oleh populasi tersebut (Sugiyono, $2011: 91$ )

Sampel dalam penelitian ini ditentukan berdasarkan pada perhitungan dari rumus solvin dengan tingkat kesalahan yang ditoleransi sebesar $10 \%$.

$$
\mathrm{n}=\frac{N}{1+\mathrm{N}(e)^{2}}
$$

Keterangan :

$$
\begin{aligned}
& \mathrm{N}=\text { ukuran populasi } \\
& \mathrm{n}=\text { ukuran sampel } \\
& \mathrm{e}=\text { margin of error, }
\end{aligned}
$$

yaitu persen kelonggaran ketidak telitian karena kesalahan pengambilan sampel yang masih dapat ditolerir sebesar $10 \%$

$$
\mathrm{n}=\frac{278}{1+278(0,1)^{2}}=\frac{278}{2,79}=75 \text { orang }
$$

Dengan menggunakan rumus diatas maka akan diperoleh jumlah sampel sebanya 75 orang karywan.

\section{HASIL DAN PEMBAHASAN}

\section{Analisis Deskriptif Berdasarkan Kuesioner \\ a. Analisis Deskriptif Karakteristik Responden}

Karakteristik responden dari 75 responden diukur dengan skala likert, menunjukkan frekuensi absolute dan presentase yang terdiri dari jenis kelamin, usia, lama kerja, dan pendidikan terakhir responden. 
Pada penelitian ini responden yang digunakan adalah karwan di bidang produksi yang terbagi menjadi beberapa bagian dan staf dan direksi PT.Adira Semesta Industry yang disesuaikan dengan teknik stratified random sampling yang melibatkan strata(tingkatan) dalam pemilihan responden. Adapun responden yang dipilih, lebih banyak melibatkan bidang produksi yang terbagi menjadi beberapa bagian yaitu sebanyak 65 orang, dan sisanya 10 orang adalah staf direksi serta manajer. Data mengenai statistik responden dapat dilihat pada tabel berikut ini:

\section{1) Jenis Kelamin Responden}

Tabel. 2.1

Data Karakteristik Responden Berdasarkan Jenis Kelamin

\begin{tabular}{|c|c|c|c|c|c|}
\hline & & $\begin{array}{l}\text { Freque } \\
\text { ncy }\end{array}$ & Percent & $\begin{array}{l}\text { Valid } \\
\text { Percent }\end{array}$ & $\begin{array}{l}\text { Cumulati } \\
\text { ve } \\
\text { Percent }\end{array}$ \\
\hline \multirow{2}{*}{ Valid } & $\begin{array}{l}\text { Laki- } \\
\text { laki }\end{array}$ & 69 & & & \\
\hline & $\begin{array}{l}\text { Wanita } \\
\text { Total }\end{array}$ & $\begin{array}{l}6 \\
75\end{array}$ & $\begin{array}{l}8,0 \\
100.0\end{array}$ & $\begin{array}{l}8,0 \\
100,0\end{array}$ & 100,0 \\
\hline
\end{tabular}

Sumber: hasil pengolahan data SPSS, 2015

Berdasarkan keterangan tabel 2.1 dapat diketahui mengenai jenis kelamin responden. Dari tabel diatas dapat diketahui bahwa jumlah responden pria lebih banyak dibanding wanita yaitu dengan persentase jumlah pria sebanyak 69 orang $(92.0 \%)$ dan jumlah rsponden wanita sebanyak 6 orang $(8,0 \%)$.

2) Usia Responden

Tabel. 2.2

Data Karakteristik Responden Berdasarkan Usia

Umur responden

\begin{tabular}{|ll|l|l|l|l|}
\hline & $\begin{array}{l}\text { Freque } \\
\text { ncy }\end{array}$ & Percent & $\begin{array}{l}\text { Valid } \\
\text { Percent }\end{array}$ & $\begin{array}{l}\text { Cumul } \\
\text { ative } \\
\text { Percen } \\
\mathrm{t}\end{array}$ \\
\hline \multirow{4}{*}{ Valid } & $18-25$ & 31 & 41,3 & 41,3 & 41,3 \\
& $26-30$ & 35 & 46,7 & 46,7 & 88,0 \\
& $30>$ & 9 & 12,0 & 12,0 & 100,0 \\
& Total & 75 & 100,0 & 100,0 & \\
\hline
\end{tabular}

Sumber: hasil pengolahan data SPSS, 2015
Berdasarkan keterangan pada tabel 2.2 dapat diketahui mengenai usia responden. Dari tabel diatas dapat diketahui bahwa responden yang berusia 18-25 tahun berjumlah 31 orang $(41,3 \%)$, sedangkan yang berusia 26-30 lebih dominan yaitu berjumlah 35 orang (36,7\%), dan responden yang berusia diatas 30 tahun berjumlah 9 orang $(12 \%)$.

\section{3) Lama Kerja}

Tabel. 2.3

Data Karakteristik Responden Berdasarkan Lama Kerja

lama bekerja

\begin{tabular}{|c|l|l|l|l|}
\hline & $\begin{array}{l}\text { Freque } \\
\text { ncy }\end{array}$ & Percent & $\begin{array}{l}\text { Valid } \\
\text { Percent }\end{array}$ & $\begin{array}{l}\text { Cumulative } \\
\text { Percent }\end{array}$ \\
\hline $0-1$ & 2 & 2,7 & 2,7 & 2,7 \\
$2-3$ & 46 & 61,3 & 61,3 & 64,0 \\
Valid $4-5$ & 19 & 25,3 & 25,3 & 89,3 \\
$5>$ & 8 & 10,7 & 10,7 & 100,0 \\
Total & 75 & 100,0 & 100,0 & \\
\hline
\end{tabular}

Sumber: hasil pengolahan data SPSS, 2015

Berdasarkan keterangan pada tabel 2.3 dapat diketahui mengenai masa kerja atau lama kerja responden. Dari tabel tersebut dapat diketahui bahwa responden yang memiliki masa kerja 0-1 tahun memiliki responden 2 orang (2,7\%), 2-3 tahun memiliki jumlah responden yang sama yaitu 46 orang $(61,3 \%)$, sedangkan responden yang masa kerja nya 4-5 tahun berjumlah 19 orang $(25,3 \%)$ dan responden yang memiliki masa kerja lebih dari 5 tahun, lebih banyak dari pada jumlah masa kerja yang lain dengan persentase jumlah sebanyak 8 orang $(10,7 \%)$.

\section{4) Pendidikan}

Tabel. 2.4

Data Karakteristik Responden Berdasarkan Pendidikan

Pendidikan terakhir

\begin{tabular}{|ll|l|l|l|l|}
\hline & & $\begin{array}{l}\text { Freque } \\
\text { ncy }\end{array}$ & Percent & $\begin{array}{l}\text { Valid } \\
\text { Percent }\end{array}$ & $\begin{array}{l}\text { Cumul } \\
\text { ative } \\
\text { Percent }\end{array}$ \\
\hline \multirow{6}{*}{ Valid } & SMP & 11 & 14,7 & 14,7 & 14,7 \\
& SMA & 62 & 82,7 & 82,7 & 97,3 \\
& S1 & 2 & 2,7 & 2,7 & 100,0 \\
& Total & 75 & 100,0 & 100,0 & \\
\hline
\end{tabular}

Sumber: hasil pengolahan data SPSS, 2015 
Berdasarkan keterangan pada tabel 2.4 dapat diketahui mengenai pendidikan terakhir responden. Dari tabel tersebut dapat diketahui bahwa responden yang dipilih secara acak dari tiap strata, memiliki tingkat pendidikan yang bervariasi. Adapun responden yang memiliki status pendidikan terakhir SMP sebanyak 11 orang $(14,7 \%)$, adapun responden yang memiliki status lebih banyak dan mendominasi yaitu pendidikan terakhir SMA berjumlah 62 orang $(82,7 \%)$, karena dalam pemilihan responden, lebih banyak ditingkat produksi, dan yang memiliki pendidikan $\mathrm{S} 1$ berjumlah 2 orang $(2,7 \%)$.

\section{Berdasarkan uji t (parsial), maka;Hipotesis 1}

Ho : Stres Kerja tidak berpengaruh terhadap

Turnover Intention.

$\mathrm{Ha}:$ Stres Kerja Berpengaruh terhadap

\section{Turnover Intention}

Pernyataan hipotesis pertama bahwa Stres Kerja berpengaruh terhadap turnover intention telah terbukti. Hal ini dapat ditunjukkan dengan nilai signifikansi pada uji regresi linier berganda bahwa Koefisien regresi untuk Stres Kerja sebesar 0,067 maka secara parsial terdapat pengaruh positif dan signifikan antara Stres Kerja terhadap Turnover Intention. Pada hasil penelitian saya ini, sesuai dengan teori dari (Robbins, 2006) Stres adalah kondisi dinamik yang di dalamnya individu menghadapi peluang, kendala (constraints) atau tuntutan (demands) yang terkait dengan apa yang sangat diinginkannya dan yang hasilnya dipersepsikan sebagai tidak pasti tetapi penting. Secara lebih khusus, stres terkait dengan kendala dan tuntutan. Kendala adalah kekuatan yang mencegah individu dari melakukan apa yang sangat diinginkan sedangkan tuntutan adalah hilangnya sesuatu yang sangat diinginkan.

Hipotesis 2

Ho : Kepuasan Kerja tidak berpengaruh terhadap Turnover Intention.

Ha : Kepuasan Kerja berpengaruh terhadap

Turnover Intention.

Pernyataan hipotesis kedua bahwa Kepuasan Kerja berpengaruh terhadap Turnover Intention . Koefisien regresi 0,097 artinya bahwa setiap peningkatan atau besarnya kepuasan kerja terhadap turnover intention sebesar satu satuan dalam skala interval akan meningkatkan kepuasan kerja terhadap turnover intention ssebesar 0,097 satuan. Dengan diketahui taraf signifikansinya sebesar 0,017 >0,05 menunjukan bahwa terdapat pengaruh negatif yang tidak signifikan antara Kepuasan Kerja dengan Turnover Intention. Kepuasan kerja adalah kepuasan pegawai terhadap pekerjaannya antara apa yang diharapkan pegawai dari pekerjaan/kantornya " (Davis, 1995 : 105). Dalam bukunya, "Perilaku Organisasi : Konsep, Kontroversi ",Robbins mengatakan: “ Kepuasan kerja adalah sebagai suatu sikap umum seorang individu terhadap pekerjaannya. Pekerjaan menuntut interaksi dengan rekan kerja, atasan, peraturan dan kebijakan organisasi, standar kinerja, kondisi kerja dan sebagainya. Seorang dengan tingkat kepuasan kerja tinggi menunjukkan sikap positif terhadap kerja itu, sebaliknya seseorang tidak puas dengan pekerjaannya menunjukkan sikap negatif terhadap kerja itu. (Robbins, 1996 : 179).

Hipotesis 3

Ho : Kepuasan gaji tidak berpengaruh terhadap Turnover Intention.

$\mathrm{Ha}$ : Kepuasan gaji berpengaruh terhadap Turnover Intention.

Pernyataan hipotesis ketiga bahwa Kepuasan gaji terhadap Turnover Intentio. Hal ini di sebabkan Koefisien regresi 0,130 artinya bahwa setiap peningkatan kepuasan kerja terhadap turnover intention dan sebesar satu satuan dalam skala interval akan meningkatkan turnover intentioni sebesar 0,130 satuan. Dengan diketahui taraf signifikansinya sebesar $0,001<0,05$ menunjukan bahwa terdapat pengaruh negatif dan signifikan antara Kepuasan Gaji dengan Turnover Intention.

Berdasarkan tabel diatas diperoleh nilai $\mathrm{F}$ hitung untuk model regresi yang digunakan sebesar 10,375. Untuk menentukan $\mathrm{F}_{\text {tabel }}$ dengan menggunakan tingkat keyakinan $90 \%, \alpha=10 \%$, dfl $(3-1)=2$, dan df2 $(75-3-1)=71$, hasil diperoleh untuk $\mathrm{F}_{\text {tabel }}$ sebesar 3,12 dan $\mathrm{F}$ sebesar 10,375. Karena Nilai $F_{\text {hitung }}>F_{\text {tabel }}(10,375>3,12$ ), maka Ho ditolak. Artinya terdapat pengaruh 
signifikan dari Stres Kerja, Kepuasan Kerja dan Kepuasan Gaji terhadap Turnover Intention.

$\mathrm{R}$ Square $\left(\mathrm{R}^{2}\right)$ atau nilai koefisien determinasi yang di peroleh dari data di atas adalah sebesar 0,305 . untuk menyatakan besar kecilnya kontribusi Variabel X terhadap Y maka Koefisien Determinan $=r^{2} \times 100 \%$ atau $0,305 \times$ $100 \%=30,5 \%$ ini menunjukan persentasi sumbangan pengaruh variabel stres kerja, kepuasan kerja dan kepuasan gaji sebesar 30,5\%, berarti pengaruh yang diberikan cukup tinggi sesuai dengan tabel pedoman interprestasi koefisien diterminasi, sedangkan sisanya sebesar $69,5 \%$ dipengaruhi oleh variabel lain yang tidak diteliti oleh peneliti.

\section{KESIMPULAN}

Berdasarkan hasil hasil penelitian, pembahasan. Dan interpretasi yang telah diuraikan pada bab-bab sebelumnya, dengan mengacu pada beberapa teori dan hasil penelitian sebelumnya, sekaligus untuk menjawab rumusan masalah pada bab sebelumnya, maka dapat ditarik kesimpulan sebagai berikut:

1. Berdasarkan hasil pengujian secara parsial (t) Pengaruh Stres Kerja terhadap Turnover Intention sebesar 4,240. Karena nilai $\mathrm{t}_{\text {hitung }}>$ $\mathrm{t}_{\text {tabel }}(4,240>1,6666)$ maka secara parsial terdapat pengaruh positif dan signifikan antara Stres Kerja terhadap Turnover Intention.

2. Berdasarkan hasil pengujian secara parsial (t) Pengaruh Kepuasan Kerja terhadap Turnover Intention sebesar -2,436. Karena nilai $\mathrm{t}$ hitung $>\mathrm{t}$ tabel $(-2,436>1,6607)$ maka secara parsial terdapat pengaruh negatif antara Kepuasan Kerja terhadap Turnover Intention.

3. Berdasarkan hasil pengujian secara parsial (t) Pengaruh Kepuasan Gaji terhadap Turnover Intention $\mathrm{t}$ hitung sebesar $-3,465$. Karena nilai $\mathrm{t}_{\text {hitung }}>\mathrm{t}_{\text {tabel }} \quad(-3,465>1,6666)$ maka secara parsial terdapat pengaruh negatif yang signifikan antara Kepuasan Gaji terhadap Turnover Intention.

4. Berdasarkan hasil pengujian secara Simultan (F) diperoleh nilai $\mathrm{F}$ hitunguntuk model regresi yang digunakan sebesar 10,375. Untuk menentukan $F$ tabel dengan menggunakan tingkat keyakinan 90\%, $\alpha=$ $10 \%$, dfl (3-1) $=2$, dan df2 (75-3-1) $=71$, hasil diperoleh untuk $F_{\text {tabel }}$ sebesar 3,12 dan $F$ sebesar 10,375. Karena Nilai $F_{\text {hitung }}>F_{\text {tabel }}$ (10,375> 3,12), maka Ho ditolak. Artinya terdapat pengaruh signifikan dari Stres Kerja, Kepuasan Kerja dan Kepuasan Gaji terhadap Turnover Intention.

5. Menurut hasil pengujuian $\mathrm{R}$ Square $\left({ }^{\mathrm{R} 2}\right)$ atau nilai koefisien determinasi yang di peroleh dari data di atas adalah sebesar 0,305 . untuk menyatakan besar kecilnya kontribusi Variabel $\mathrm{X}$ terhadap $\mathrm{Y}$ maka Koefisien Determinan $={ }^{\mathrm{r} 2} \times 100 \%$ atau $0,305 \times 100 \%=30,5 \%$ ini menunjukan persentasi sumbangan pengaruh variabel stres kerja, kepuasan kerja dan kepuasan gaji sebesar $30,5 \%$, berarti pengaruh yang diberikan cukup tinggi sesuai dengan tabel pedoman interprestasi koefisien diterminasi, sedangkan sisanya sebesar $69,5 \%$ dipengaruhi oleh variabel lain yang tidak diteliti oleh peneliti.

\section{REFERENSI}

Andini, Rita, 2006. Analisis Pengaruh Kepuasan Gaji, Kepuasan Kerja,Komitmen Organisasional Terhadap Turnover Intention. Thesis. Program Studi Magister Managemen, Program Pasca Sarjana, Universitas Diponegoro, Semarang.

Chen, Z. X. Dan Francesco, A. M. 2000.

“ Employe Demography, Organizational Commitment, and Turnover Intentions in China: Dorulcutural differences matter?" Human Relations 53 (6): 874

Darmanto dan Subagyo,S.,2007. Pengaruh Professional dan Organizational Commitment, Kepuasan Kerja dan Turnover Intention terhadap Kinerja Dosen. Laporan Penelitian. Fakultas Ekonomi/Prodi Manajemen, Universitas 17 Agustus 1945, Semarang.

Lum, L., Kervin, J., Clark K., reid, F. \&Sirola, W - 1998. Explaining Nursing Turnover Intention: Job Satisfaction, Pay Satisfaction, or Organitational Commitment?. Journal of 
Organoizational Behavioral, 19: 305320.

Mino 2006 meneliti Pengaruh Stres Kerja dan Kepuasan Kerja Terhadap Turnover IntentionKaryawan (Studi pada STIKES Widya Husada Semarang) di Ponogoro Journal of accouting Volume 1, Nomor 1, Tahun 2012, Halaman.

Kinicki, Angelo and R. Kreitner, 2005, Organizational Behavior Key concepts skills and best Practice, Mc Graw-Hill, New York, hal. 125 